\title{
Constitutional Mimicry and Common Law Reform in a Rights-Based Post-Colonial Setting: The Case of South Africa and Malawi
}

\author{
Sibo Banda*
}

\begin{abstract}
Competent courts in Malawi must, as courts have done in South Africa, undertake a radical path in order to enhance the common law position of distinct categories of persons. This article discusses judicial appreciation of the common law-changing function of a bill of rights and its associated values, and judicial understanding as to when such a function may be brought into play. The article examines approaches taken by courts in South Africa in determining the circumstances in which the South African Bill of Rights applies to private relationships, when private parties owe each other duties arising out of the Bill of Rights and the scope of a court's authority to amend the common law in that regard. The article projects the debate, analysis and critique of these approaches onto the Malawian legal landscape through a discussion of the tenant worker contracted on the Malawi private estate.
\end{abstract}

\section{INTRODUCTION}

The competent common law court in Malawi must take steps to develop private common law in order to enhance the common law position of distinct categories of persons through the indirect horizontal application of the Bill of Rights. ${ }^{1}$

This paper discusses bills of rights, private relationships and judges' potential role in advancing the constitutional aim of making private law more responsive to constitutional requirements. This article aims to graft this discussion onto the Malawian jurisprudential landscape by studying the case of the tenant worker who is contracted under a tenant worker's contract on a private estate. $^{2}$

* LLB (Malawi), LLM (Warwick), PhD (University College Cork). Lecturer, National University of Ireland, Maynooth. Email: sibo.banda@nuim.ie.

1 The Bill of Rights constitutes chapter IV of the Republic of Malawi (Constitution) Act (no 20 of 1994) (the Malawi Constitution).

2 S Banda "Land law reform: A comparative analysis of South Africa's labour tenancy contract and Malawi's tenant worker's contract" (2006) 6(2) Oxford University Commonwealth Law Journal 201. Also known as "tenant sharecropper"; the term "tenant sharecropper" appears in sec 3 of Malawi's Employment Act 1999 (no 6 of 2000). 
First, the article assesses the nature of the dialogue in Malawi on the horizontal application of the Bill of Rights. ${ }^{3}$ This is followed by an analysis of the tenant worker on the private estate in Malawi and a brief description of the attendant social and tenure environment. A case is made for a radical approach that overrides the orthodox approach of the common law to land tenure rights. Furthermore, the article explains the theoretical bases for potential judicial resistance to reception of the rights discourse that impacts on Malawi's common law approach. In making this case, South Africa ${ }^{4}$ is proposed as a viable model for Malawi.

Citing South African jurisprudence as a model, the article discusses it from a judicial perspective. First, it identifies specific arguments advanced to alter the balance between rights and duties in private relationships and to effect adjustments in the relative positions of the holders of rights and duties. It examines under what circumstances the South African Bill of Rights is relevant to private relationships. Further, it considers what sets of facts and legal issues are expressly or implicitly contemplated by the South African Bill of Rights as a source of obligations, in the event that private parties are held to owe each other duties. In a situation that is generally recognized as being contemplated by the South African Bill of Rights, the article examines what scope of authority a court has to amend the common law, to create a right or to impose a duty in the face of conflicting interests.

Using insights gleaned from the South African context, the tenant worker's claims are analysed on the basis of the provisions of the Malawi Constitution and the values that underlie it. The discussion aims to engage, from a deeper analytical perspective, a debate that is at best nascent in Malawi. Hitherto, the voices that attempt to stoke such a debate have remained lonely cries in a wilderness of conformism and conservatism. ${ }^{5}$

\section{TRACING THE BARELY CHARTED: DIALOGUE ON THE BILL OF RIGHTS IN THE MALAWI CONSTITUTION, PRIVATE LAW AND PRIVATE RELATIONSHIPS}

Having set out to graft the discussion of bills of rights and private relationships onto Malawi's jurisprudential landscape, this article will assess the dialogue on the horizontal application of the Malawi Bill of Rights. As will be clear,

3 The Bill of Rights provides a framework that coheres with, or a foundation that expressly authorizes, the enhancement of the common law position of specific classes. A Fagan "Determining the stakes: Binding and non-binding bills of rights" in D Friedmann and D Barak-Erez (eds) Human Rights in Private Law (2001, Hart) 73 at 94-95.

4 The Constitution of the Republic of South Africa Act no 108 of 1996 (the South African Constitution) and its predecessor the Constitution of the Republic of South Africa, Act no 200 of 1993 (Interim Constitution).

5 S Gloppen and FE Kanyongolo "Courts and the poor in Malawi: Economic marginalization, vulnerability and the law" (2007) 5 International Journal of Constitutional Law 258 at 264 (giving reasons why litigation around the Bill of Rights is unsatisfactory). 
the debate is limited in scope. This may be due to "path dependency", ${ }^{6}$ unwillingness rationalized on the basis of consistency or mere lack of exposure to the relevant technical approaches.

\section{The constitutional rights-based discourse: The present state of affairs}

Under section 15(1), the Malawi Constitution affirms both the vertical and horizontal justiciability of the Bill of Rights. The courts in Malawi have accepted that the Bill of Rights may, horizontally, be invoked directly. To use the words of Peter Benson, the rights "... just as they are defined ... are to be applied directly ... to relations between private individuals. The definition and vindication of these rights are fully independent of the doctrines and operation of private law."7

The Bill of Rights does not mention indirect application, that is the application of the rights to transactions between private individuals "channeled through the doctrines, methodology and procedures of private law". 8 The Bill of Rights does not state whether it is applicable to the law in force in Malawi. ${ }^{9}$ Section 10(2) of the Malawi Constitution provides sufficient authority and requires that, in the application and development of the law in force, "due regard" must be paid to the constitutional principles and provisions. The term "Constitution" necessarily includes the Bill of Rights. ${ }^{10}$ Furthermore, the reasons and justification for the horizontal application of the Bill of Rights may be obtained from the spirit, intent and values that underpin the Malawi Constitution. ${ }^{11}$

The jurisprudence of Malawi is not immune to the uncertainty that girds the horizontal application of a bill of rights. Chirwa has observed that the courts in Malawi have not responded "systematically" to the question of when a litigant may seek direct horizontality and states: "In practice, where a claim involves an infringement of human rights, legal practitioners have

6 OA Hathaway "Path dependence in the law: The course and pattern of legal change in a common law legal system" (2001) 86 Iowa Law Review 601.

7 P Benson "Equality of opportunity and private law" in Friedman and Barak-Erez (eds) Human Rights, above at note 3, 201 at 205. See discussion below on Liquidator, Import and Export (Mw) Limited $v$ JL Kankhwangwa and Others, High Court of Malawi, principle registry, civil appeal no 52 of 2003 (unreported), available at: <http://www.saflii.org/mw/cases/ MWHC/2003/92.html> (last accessed 1 September 2007).

8 Benson, ibid.

9 Sec 200 provides that unless "inconsistent with this Constitution, all Acts of Parliament, common law and customary law in force on the appointed day shall continue to have force of law".

10 Sec 11(2)(b) of the Malawi Constitution stipulates that in the interpretation of law a court must take full account of the Fundamental Principles and the Bill of Rights incorporated in chaps III and IV respectively of the constitution.

11 Id, sec 11(1) requires courts to develop appropriate principles for interpreting the constitution which show "its unique character". See also Fagan "Determining the stakes", above at note 3; and LE Weinrib and EJ Weinrib "Constitutional values and private law in Canada" in D Friedman and D Barak-Erez (eds) Human Rights, above at note 3, 43. 
been allowed to claim remedial action by relying on 'private law causes of action' or directly on the Constitution or both" 12 (emphasis added). For Chirwa, "[t]he correct way, based on the practice in Ireland, would be to insist on the principle that litigants should base their actions directly on the constitution only when the private law remedies relating the human rights violation in question are inadequate or non-existent."13

The phrase "private law causes of action" is ambiguous. It is not clear whether "private law causes of action" means that the Bill of Rights will apply in private disputes indirectly through the development (either expansion or contraction) of common law doctrines, principles and methodology. Alternatively, clarity is needed on whether the common law can sufficiently and independently deal with a particular grievance even though the breach infringes a provision in the Bill of Rights. ${ }^{14}$ It appears that Chirwa's view is that an infringement of the Bill of Rights provision may be dealt with either independently by private common law or alternatively that it may addressed through direct horizontality. However, it is important to recognize the existence of indirect horizontal approaches that may impact on a factual situation through the common law. ${ }^{15}$ Furthermore, the common law itself may be the source of offence and a bill of rights provision may be used to expand or contract the common law in order to correct the situation. ${ }^{16}$

The author construes Chirwa's recommendation as essentially about the correct procedural sequencing of actions based on independent private law remedies and those based on direct horizontality. While this approach may be justified on the basis that it makes "logical and operational sense", 17 it is difficult to see how this view can be sustained as an absolute position. Unlike the Irish Constitution, the Malawi and South African Constitutions expressly authorize direct and indirect horizontality. The call for prior determination of whether independent "private law remedies in relation to human rights violations are inadequate or non-existent" masks a jurisprudential

12 DM Chirwa "A full loaf is better than half: The constitutional protection of economic, social and cultural rights in Malawi” (2005) 49(2) Journal of African Law 207 at 236.

13 Id at 236 (footnote omitted). In relation to Ireland, Chirwa cites the leading text on Irish Constitutional Law: G Hogan and G Whyte The Irish Constitution (JM Kelly) (1994, Butterworths) at 777 and the cases of Hanrahan $v$ Merck Sharp and Dohme (Ireland) Ltd [1988] ILRM 629 and Meskell v CIE [1973] 1 IR 121.

14 Generally judges and legal practitioners in common law jurisdictions are reluctant to use human rights law to develop private common law due to "constitutional" and "institutional” reasons. R Bagshaw "Privacy and tort design” in KS Zeigler (ed) Human Rights and Private Law: Privacy as Autonomy (2007, Hart) 79 at 80 and B McMahon and W Binchy Law of Torts (3rd ed, 2000, Butterworths) at paras 122-30.

15 AL Young "Horizontality and the Human Rights Act, 1998" in KS Zeigler (ed) Human Rights and Private Law, above at note 14, 35 at 39-41.

16 This is recognized in Granger Nkhwazi v Commercial Bank of Malawi Limited civil cause no 233 of 1999 (21 November 2003) (unreported), available at <http://www.saflii. org/mw/cases/MWHC/2003/81.html> (last accessed 1 September 2007). 
question that is complex and potentially controversial, both from a substantive and procedural perspective.

The question relates to the consideration of specific principles of application and interpretation incorporated in the Malawi and South African Constitutions. ${ }^{18}$ These principles are neither capable by themselves of transmitting clear guidelines about the reach of the bill of rights and constitutional provisions nor the circumstances of their invocation. Rather, they require elaboration by a court; the approach adopted by South African courts presents an informative point of departure for the development of applicable guidelines. It explains and confirms an alternative way of conceptualizing the constitutional legal system: one that places primacy on the constitution as opposed to parliament. ${ }^{19}$ It also provides a basis for exploring the reach of these principles and provisions, and the determination of the circumstances of their invocation. Chirwa's view on sequencing raises inevitable, implicit and significant questions concerning the determination of "inadequacy" or "non-existence" of remedies in private law: who should determine this, how is it to be determined and when should the determination be made. ${ }^{20}$

For the purpose of this article, it suffices to observe that this discussion does not consider whether the courts in Malawi have engaged with the deep substantive jurisprudential questions relating to indirect horizontality and the underlying values that inform them. By contrast, courts in South Africa have engaged actively with the difficult questions pertaining to horizontality and private relationships. The quality of this debate has of course benefited from broad intellectual contributions from both inside and outside South Africa. $^{21}$

The aim of this article is to help launch a dialogue on Malawi with regard to the qualitatively substantive aspects that gird the jurisprudence of the relationship between the Bill of Rights and private actors. It will examine whether the courts have attempted to analyse indirect horizontality robustly. It does not cover a comprehensive review of case law but tests the thesis that the debate has been limited in scope in terms of analysis and impact. Next this article will discuss the Liquidator, Import $\mathcal{E}$ Export $(\mathrm{M} w)$ Limited $v \mathrm{JL}$ Kankhwangwa $\&$ Others (the Liquidator's case) and Granger Nkhwazi

18 In South Africa sec 39(2). For Malawi, see note 10 above.

19 See notes 10 and 11 above. On the nature of principles, see T Tridimas The General Principles of EC Law (1999, Oxford University Press) at 1-4.

20 In Ireland, Irish academics point out that courts have not dealt with this in a comprehensive manner. See B McMahon and W Binchy Law of Torts, above at note 14 at para 1.17-1.73; C O'Cinneide "Grasping the nettle, Irish constitutional law and direct horizontal effect" in J Fedtke and D Oliver (eds) Human Rights in the Private Sphere: A Comparative Study (2007, Routledge-Cavendish) 213.

21 DM Davis "Constitutional borrowing: The influence of legal culture and local history in the reconstitution of comparative influence: The South African experience" (2003) 1 International Journal of Constitutional Law 181. 
$v$ Commercial Bank of Malawi Limited cases. ${ }^{22}$ The article argues that the analysis in the first of these cases was limited and resulted in a lost opportunity to set a precedent for indirect horizontality. It argues that the analysis in the latter case of the relationship between private common law and the Bill of Rights was, substantively and jurisprudentially, given depth although its potential impact is limited. Furthermore, the technical analysis of the bases of indirect horizontality in both cases is non-existent.

\section{The Liquidator's case}

The respondents' employment had been terminated following the winding-up of the company. In issue was whether the law required that employees be repatriated to their district of origin or to their place of recruitment. For a proper and clear context, a brief sociological and legal background is required. In the southern Africa region, inter- and intra-territorial migration has played an important role in the evolution of the labour market. ${ }^{23}$ In Malawi intraterritorial migration continues to be an instrument for the engagement of labour into capitalist relations. Intra-territorial migration involves the movement of workers either on their own account or through the activities of unregulated "professional" recruiters from one district of Malawi to another. Under section 16 of the Employment Act 1964 the employer was obliged to repatriate the recruited worker on the termination of an employment contract. ${ }^{24}$ In 2000 this act was repealed by the Employment Act 1999, ${ }^{25}$ which included provisions that regulated recruitment and repatriation.

The respondents argued that, following the repeal, repatriation had become a matter of common law practice and custom. The chairman of the Industrial Relations Court at first instance found in favour of the respondents and cited section 31(1) of the Malawi Constitution (section 31) which guarantees fair labour practices. Apparently the chairman's concern was the capacity of recruited workers to manage or avoid risk following termination. The chairman apparently accepted that repatriation had become a matter of practice and custom in employment ${ }^{26}$ and, in his view:

"[It is] a requirement of fair practices as put in Section 31 of the Constitution, that upon termination of employment, the employee has to be repatriated to his/her place of abode ... As the court was told, most of those who were terminated of their services are just languishing in the cities or districts [sic]

22 See above at notes 7 and 16. The Bill of Rights and private common law link appears to have mostly been dealt with in the area of labour law. See C Ng'ong'ola "Recent labour law reforms in Malawi: A review” (2002) 46(2) Journal of African Law 167.

23 B Freund The African Worker (1988, Cambridge University Press).

24 A recruited worker's link with family or the social security systems of their communities of origin is tenuous. Given the ineffectiveness of the state funded social security system, a recruited worker may not manage or avoid the risk resulting from termination.

25 Ng'ong'ola "Recent labour law reforms", above at note 22 at 184 (footnote 76).

26 For the chairman it was relevant that the employees were not culpable. 
stations. Some, the court was told have been evicted from the houses by the New [sic] owners. This, I take is a catastrophic situation and it is a human rights abuse." 27 (Emphasis added)

This is a contextual construction of the provision sensitive to the employment of Malawi society. What is not clear though is whether the chairman was attempting to create a constitutional right through direct horizontality. Alternatively was the chairman developing the common law in a manner which resurrects the provision of the now repealed Employment Act 1964? In other words was the chairman expanding the common law through indirect horizontality? ${ }^{28}$

On appeal Kapanda J stated that repatriation had neither become a matter of common law practice and custom nor was there a statutory basis for it. He observed that repatriation "must have had its basis on the statutory law as it stood then". Following the repeal of the Employment Act 1964 it "must be considered as if it had never existed". ${ }^{29} \mathrm{He}$ also stated that "it is a trite proposition of law that at the end of the contract of employment the employer is responsible for repatriation expenses of the employees to the place of recruitment or to any other place which the two parties have agreed". ${ }^{30}$ (Emphasis added)

Nevertheless, the court confirmed and modified the chairman's order for the repatriation of the respondents. ${ }^{31}$ The effect of the finding of the court was that: (a) the High Court agreed with the chairman of the Industrial Court that the employees be repatriated; and (b) the High Court interpreted section 31 as requiring that the employees be repatriated to their place of recruitment or their home of origin, whichever is nearer. ${ }^{32}$

Crucially it is not clear from the analysis in the judgment whether the decision was based on legislation, on section 31 or on the common law. The observation that it is a "trite proposition of law" that the employer meets repatriation "expenses" suggests the decision was based on the repealed Employment Act 1964. This is sound so long as it is accepted that the

27 Liquidator, above at note 7.

28 An issue here is that in either case the chairman would be exceeding his jurisdiction as noted on appeal by the High Court.

29 Liquidator, above at note 7. An established position across many common law jurisdictions including Malawi would hold that, since the contract of employment was constituted while the Employment Act 1964 was in force, the relevant provisions must be taken as saved by the Employment Act 1999. See Hamilton $v$ Hamilton [1982] IR 466 at 480-81.

30 Liquidator, above at note 7. This statement muddies the water. "Trite proposition of law" implies that the principle is well established and continues to be effective.

31 While the chairman did not clarify whether there was a distinction between recruited workers and workers engaged in an ordinary way, the High Court appeared to make this distinction and suggested that only recruited workers could be repatriated.

32 The difference here is that the appellant is given a choice either to effect repatriation or simply to meet its cost. 
employees were recruited while the repealed act was in force and that the employer was bound by its relevant provisions saved by the repealing act, the Employment Act 1999. Alternatively, reconciling "trite proposition of law" with section 31 is difficult since no court up to this point had discussed the issue of repatriation in its context. Similarly it is difficult to argue that the "trite proposition of law" was based on the common law since this would be inconsistent with Kapanda J's rejection that repatriation "had become a matter of common law practice and custom". ${ }^{33}$

The court's identification of section 31 suggests that the court is creating constitutional rights and duties through direct horizontality. The court had the opportunity to apply section 31 indirectly and thus to create a common law rule on repatriation. In the light of the repeal of the Employment Act 1964 and the brutal facts of the sociological reality of recruitment in Malawi, it would have been possible to justify this approach. Although the effect of the chosen approach is ultimately similar to indirect horizontality, this article argues that the court lost an opportunity to set a desperately needed precedent on the indirect horizontal approach. The argument made on behalf of the respondents and taken on board by the chairman was constitutionally sound from the perspective of indirect horizontality. Nevertheless, the argument appears to have been undermined by the lack of a robust and explicit elaboration of the role of indirect horizontality and its technical basis. $^{34}$

\section{Granger Nkhwazi's case}

The plaintiff sued for wrongful termination of services. The defendant argued that the termination was done in accordance with the orthodox common law principle that "in ordinary circumstances, by giving the appropriate notice, a master can terminate his servant's employment and no one can question the motives of the master in reaching a decision to do so". ${ }^{35}$ Assuming this was borne out by the facts, and subject to constitutional compliance, the defendant was on firm ground at common law. The facts giving rise to the action occurred at a time before the Employment Act 1999 was operational but after the Malawi Constitution came into force. Consequently the applicable law was the Constitution, the Employment Act 1964 and the common law.

Mwaungulu J noted that the evidence, and therefore the common law, did not support the defendant's contention. The facts of the case could be distinguished from the type of case that could rightly rely upon the orthodox common law statement. ${ }^{36}$ The facts showed that the defendant suspended the plaintiff from his duties in order to facilitate an investigation into allegations

33 Liquidator, above at note 7.

34 For examples of explicit elaboration, see notes 7, 8, 9, 10 and 11 above.

35 Barry J in Barber $v$ Manchester Regional Hospital Board [1958] 1 ALL ER 322 at 329 and adopted in Malawi in Mwalwanda $v$ Press (Holdings) Ltd (1981-83) 10 MLR 321.

36 Mwaungulu J cited Tomlinson v London, Midland and Scottish Railway Co [1944] 1 ALL ER 1278. 
made against the plaintiff and an adverse finding against the plaintiff would result in his dismissal. The defendant failed to carry out the investigation but nonetheless proceeded to terminate the employment contract. Mwaungulu J found the defendant culpable. Significantly, Mwaungulu J reconsidered the relationship between "section 31(1) of the Malawi Constitution on 'fair labour practice' ... [and] the common law principle that the employer could terminate lawfully if she acts according to contract by giving notice to the employee as a fair labour practice". He felt obliged to address the issue since section 57 of the Employment Act 1999 could not be relied upon by persons for whom the new employment law regime was inapplicable on account of retroactivity. ${ }^{37}$ He considered that an employer cannot continue to rely on the impugned common law principle because of the respect courts have for "natural justice principles and rights citizens have under the 1994 Constitution". Furthermore:

\begin{abstract}
"The duty to apply principles of natural justice, in my judgment, does not only arise where the employer gives reasons for termination. It arises in any case, even if the employer does not state the reasons for termination, where the employer terminates for the employee's conduct .... . One has a duty to justify. The other has a legitimate expectation for the justification ... . Our common law should, if not already developed that way, develop that way." 38 (Emphasis added)
\end{abstract}

An obvious question is what is the implication for indirect horizontality? The judge was calling for the development of the common law in order to bring it in line with the stipulation in section 57 of the Employment Act 1999 and thus to avoid disparate treatment by statute and the common law. The development of the common law in this respect is not based on the judge's jurisdiction inherent in the common law but on the authority of section 31. This is a clear example of indirect horizontality and an instance of the expansion of legal duties and rights in the common law.

However, the judge distinguished Granger Nkhwazi's as one in which an "employer gives reasons for termination". He invoked section 31 in relation to an aspect of the common law rule different from the issue in dispute. Section 31 was invoked with regard to lawful termination of contract where "the employer does not state the reasons for termination". The views expressed by the judge were therefore obiter and did not constitute the reason for the decision.

That "[o]ur common law should, if not already developed that way, develop that way" is an attempt to develop the common law using indirect horizontality. Although a welcome development, its impact is potentially limited. First the opinion of the judge in this respect is not binding. It is simply a statement

37 The section permits termination only for "a valid reason connected with the capacity or conduct of the employee or based on the operational requirements of the undertaking". 
that is directory in nature and certainly not the basis of a precedent. Secondly section 31 was invoked on an issue that was peculiar to the circumstances of the case. The suggested development of the common law is only applicable to situations where the Employment Act 1999 is inapplicable on account of retroactivity. Therefore the potential impact of the case is dependent on the unlikely event (due to the statute of limitations) of a similar case appearing before the courts. Significantly, the judge does not explicitly link the discussion of indirect horizontality to the constitutional provisions that provide authority for its use. ${ }^{39}$

Having traced the dialogue on the indirect horizontality the article will now discuss the case of the tenant worker on the private estate. It will show that reform of the common law is necessary in this regard.

\section{A CONTEXT FOR HORIZONTALITY: THE TENANT WORKER, THE TENANT WORKER'S CONTRACT AND PRIVATE ESTATE LEGISLATION}

The tenant worker class, desperately poor, depends on land access for economic and social sustenance. Although the deplorable social, economic and legal situation of tenant workers on private estates has been acknowledged in various fora, Malawi's land policy makes no reference to them. Proposed reforms will therefore not address the social, economic or legal deficits underlying their plight. ${ }^{40}$ Efforts to enact corrective legislation outside the land law reform process have met with no success. ${ }^{41}$

Under the tenant worker's contract, a private estate owner grants the tenant worker access to a parcel of land, as well as material agricultural inputs and services, in consideration for the tenant worker's undertaking to produce and sell agricultural commodities to the owner. ${ }^{42}$ The Africans on Private Estates Act (Private Estates Act), ${ }^{43}$ in particular section 25, provides a legislative framework for regulating a contractual relationship defined as a "special agreement". Functionally, the special agreement provides a legal framework for the creation of contractual relationships (not limited to a particular type of contract) whose primary purpose is the production of commodities, referred to under the Private Estates Act as economic crops. The tenant worker's contract, therefore, has the potential to be constituted as a special agreement. However, due to strategic economic reasons, the Private Estates Act has not been applied to any such contractual relationship. ${ }^{44}$ The minister

39 See notes $10,11,12,13$ and 14 above.

40 Republic of Malawi Ministry of Lands, Housing, Physical Planning and Surveys Malawi National Land Policy (2002) at 1.1.3-1.1.4 and 2.3-2.4, available at <http://www.malawi. gov.mw/publications/landpol.htm> (last accessed 20 March 2007).

41 A bill to regulate the tenant worker's contract independently from the land reform process has been in the legislative process for the last ten years.

42 Banda "Land law reform", above at note 2 at 201.

43 No 12 of 1962.

44 Banda "Land law reform", above at note 2 at 211 (footnote 53). 
has not used his power under the Private Estates Act to ensure that commodity production contractual relationships on private estates, including the tenant worker's contract, are regulated accordingly.

The purpose of section 25 is to give adequate security of tenure to persons contracted by private estate owners to produce economic crops and to ensure fairness and equity in these contractual relationships. It calls for the minister to assess contracts (potentially including tenant workers' contracts) to determine whether they adequately secure the contractors' tenure and that fairness and equity are guaranteed. ${ }^{45}$ However, section 25 is permit-based, as opposed to rights-based;46 it depends on the initiative of the minister to bring it into operation in relation to a particular private estate. This has been ineffective because the minister has taken no such initiative.

Section 25 of the Private Estates Act, which is intended to protect a contracted person from economic, social and legal vulnerabilities, potentially enables the tenant worker to attain a dignified existence. Often the contract sets up a patron/client relationship and is susceptible to unjust and exploitative tendencies which include unlawful summary eviction and disregard of contractual provisions that secure the tenant worker's tenure. Tenant workers are often landless intra-territorial migrants compelled by circumstances to work on private estates. They are unable to negotiate for themselves favourable terms or to have them enforced through legal process. ${ }^{47}$ Furthermore, a tenant worker's contract is an economic undertaking. A tenant worker requires as a minimum a contractual relationship that allows him effectively and fairly to negotiate those terms of the contract that impact on financial viability. However, empirical evidence suggests that the tenant worker does not have effective bargaining power in such matters. ${ }^{48}$ Section 25 is intended to provide a mechanism to prevent or control such practices and to improve the tenant worker's bargaining capacity. Consequently the placement of the tenant worker's contract outside the framework of the Private Estates Act undermines efforts to prevent unjust and exploitative tendencies.

45 Sec 25 of the Private Estates Act provides: “(1) Any owner may enter into a written special agreement with any African [who] ... is entitled to reside on the estate of such owner; (2) ... an African who enters into such agreement shall be required to work for the owner of the estate for such period during the year as may be agreed upon; Provided that: ... (b) no agreement shall be approved by the minister as a special agreement unless he is satisfied that it provides for adequate security of tenure ... and is fair and equitable in all circumstances." (Emphasis added)

46 P McAuslan "Making law work: Restructuring land relations in Africa" (1998) 29 Development and Change 525 at 528.

47 Gloppen and Kanyongolo "Courts and the poor in Malawi", above at note 5.

48 For example L Tørres (ed) The Smoking Business: Tobacco Workers in Malawi (2000, Fafo) at chap 3; Institute for Applied Social Science, Oslo Fafo Report No 39: "Tobacco tenants in Malawi", available at <http://www.fafo.no/pub/rapp/339/> (last accessed 8 September 2007) at 339 (explaining these risks in the particular case of Malawian tobacco tenant workers). 
In the absence of effective intervention based on section 25, the tenant worker may have to turn to the competent common law courts. Under a traditional analysis, the prospects for relief under the common law are uncertain, given the analytical difficulties a common law court would face. It must be pointed out, moreover, that these analytical difficulties are equally pertinent to the potential role of the minister under section 25. For example, a minister's intervention on account of lack of fairness or equity may be resisted on the ground that the terms fairness and equity lack specificity; under the common law principles of administrative law, "where one is to affect another's rights adversely for a reason the other reasonably expects to be satisfied of the reason". ${ }^{49}$ Resistance may also be based on alleged interference with the autonomy and sanctity of contract as well as with ownership of private property. Thus, even where judicial intervention is sought to compel the minister to apply the Private Estates Act, a common law challenge might be raised on these grounds.

\section{The problem with the common law approach on the private estate}

A request seeking redress in order to attain adequate security of tenure, fairness and equitable terms is inconsistent with the rationale underlying the concepts of security of tenure, fairness and equity under orthodox common law. Underlying section 25, and the tenant worker's claim, are considerations that are distributive in nature. The following examination of the analytical difficulties a common law court would face is limited to discussing the concept of adequate security of tenure.

The conventional usage of the term "security of tenure" under the common law retains features that contradict and potentially subvert the aim of the special agreement to impose distributive considerations on transactions between contracting parties. It is not directed toward distributive justice. Security of tenure is a technical requirement in the mechanism for lawful access to private land. Under orthodox common law it does not extend to correcting the substantive equality deficit that may inhere in the terms of the contract and in the extrinsic respective positions of the parties. Attempts to seek judicial intervention to attain the distributive objective inherent in the request for adequacy of security of tenure would fail.

The tenant worker's contract is a land access contract and is capable of being constituted as a lease, a tenancy agreement, a contractual licence, a licence coupled with an interest or a contract sui generis [innominate contract]:50 essentially contracts subject to the principles of contract law. This area of law has retained at its core the freedom of contract ethos or the liberal

49 Granger Nkhwazi, above at note 16.

50 See the South African case of De Jager $v$ Sisana 1930 AD 71 at 84 and Banda "Land law reform", above at note 2 at 209. 
conception of contract. ${ }^{51}$ The basic aim of the liberal individualism that inheres in this view is to guarantee the individual's freedom from external interference. ${ }^{52}$ The corollary of the ascription of self-determination to the individual in this liberal conception is the sanctity of contract, the obligation placed on society to respect the choices the autonomous agent makes. Consequently the voluntary choices made by an autonomous individual in a contractual bargaining process, good or bad, must be allowed to stand without interference. ${ }^{53}$

This liberal view of contract is inherent in the common law and influences the common law judge's understanding of contract law. This causes Rick Bigwood to call the common law of contract "a prisoner of ineradicable practical and ideological constraints". ${ }^{54}$ Security of tenure thus refers to a consensus between the parties as to the period the estate acquired in the land in question is to run. Courts can only intervene vis-à-vis security of tenure in respect of procedural questions. Pursuant to the liberal view of contract, “... a contract need only fit the form ... supported by some consideration ... mere inadequacy of consideration will not void a contract". ${ }^{55}$ Intervention will not be entertained on the question of adequacy; it is permissible only when impropriety is attributable to either party.

The common law's approach is essentially located in a corrective justice mould and its legitimacy based on correlativity. ${ }^{56}$ In order for the common law to intervene, the complainant must show that her failure to secure a term of tenure favourable to her situation was a consequence of an act of the other contracting party. Without this correlative link, the common law maintains a respectful distance from the predicament of the tenant worker and, thus, preserves the privileged position occupied by the private estate owner. It intervenes only when that privileged position is patently abused. That said, South Africa provides a possible bill of rights based model by which private law can be made more responsive to constitutional requirements.

51 KM Sharma "From 'sanctity' to 'fairness': An uneasy transition in the law of contracts?" (1999) 18 New York Law Journal of International and Comparative Law 95 at 115.

52 M Rosenfeld "Contract and justice: The relation between classical contract law and social contract theory” (1985) 70 Iowa Law Review 769 at 778.

53 M Lobban "Contractual fraud in law and equity c1750-c1850" (1997) 17 Oxford Journal of Legal Studies (OJLS) 441 at 441.

54 R Bigwood "Conscience and the liberal conception of contract: Observing basic distinctions” (2000) 16 Journal of Contract Law part 1, 1 at 44.

55 JS Lim "Tongue-tied in the market: The relevance of contract law to racial-language minorities" (2003) 91 Californian Law Review 579 at 590.

56 P Cane "Corrective justice and correlativity in private law" (1996) 16(3) OJLS 471; EJ Weinrib The Idea of Private Law (1995, Harvard University Press) and R Bigwood "Contracts by unfair advantage: From exploitation to transactional neglect" (2005) 25 OJLS 65. 


\section{HORIZONTALITY AND THE CONSTITUTIONAL RIGHTS-BASED DISCOURSE IN SOUTH AFRICA}

Constitutionally South African courts may determine the circumstances in which a bill of rights should be applied to private relationships, when the parties in such relationships will owe each other duties and also the scope of their authority in that regard. Before the entry into force of the Interim and South African Constitutions, the common law, subject to the principle of parliamentary supremacy, enjoyed complete independence from the apartheid constitution and had exclusive jurisdiction in the regulation of private relationships. The relationship between the common law and the constitution has since changed, making it the duty of judges to ensure that the common law, in its application and, where necessary, its development, is consistent with constitutional provisions.

\section{One system, one law: A new relationship between the constitution and the common law in South Africa}

The vehicle for extending constitutional provisions to private conduct is provided by sections 8(2), (3) and (39)(2) of the South African Constitution. ${ }^{57}$ The consideration of these sections and how they have been invoked provides a concrete basis for reflection on options open to courts in Malawi. Section $8(2)$ stipulates: "A provision of the Bill of Rights binds a natural or a juristic person if, and to the extent that, it is applicable, taking into account the nature of the right and the nature of any duty imposed by the right." Section $8(3)$ reads:

"When applying a provision of the Bill of Rights to a natural or juristic person in terms of subsection (2), a court:

a) in order to give effect to a right in the Bill, must apply, or if necessary develop, the common law to the extent that legislation does not give effect to that right; and

b) may develop rules of the common law to limit the right ... in accordance with section 36(1)."

57 S Woolman and D Davis "The last laugh: Du Plessis and Others $v$ De Klerk and Another, classical liberalism and the application of fundamental rights under the interim and final constitutions" (1996) 12 South African Journal on Human Rights (SAJHR) 36; AJ Van der Walt "Exclusivity of ownership, security of tenure and eviction orders: A critical evaluation of recent case law" (2002) 18 SAJHR 372; J Van der Walt "Progressive indirect horizontal application of the Bill of Rights: Towards a co-operative relation between common-law and constitutional jurisprudence" (2001) 17(3) SAJHR 341; CJ Roederer "Post-matrix legal reasoning: Horizontality and the rule of values in South African law" (2003) 19 SAJHR 57 and C Roederer "The transformation of South African private law after ten years of democracy: The role of torts (delict) in the consolidation of democracy" (2006) 37 Columbia Human Rights Law Review 447. 
Section 39(2) provides: "When interpreting any legislation, and when developing the common law or customary law, every court, tribunal or forum must promote the spirit, purport and objects of the Bill of Rights."

In the case of Khumalo $v$ Holomisa ${ }^{58}$ O'Regan J explained that where it was determined that section 8(2) applied a court was, on the basis of section 8 (3), under a duty "to apply and if necessary develop the common law". ${ }^{59}$ In regard to section 39(2), O'Regan observed that, although it did not apply directly, the principles of the common law had to be applied and developed by courts "with due regard to the spirit, purport and objects" of that constitution's bill of rights. ${ }^{60}$

The implication here is that, where applicable, section 8(2) provides the basis for direct application of the South African Bill of Rights to relationships between private individuals. Direct application of a constitutional provision provides the basis for instituting a cause of action where, as Johann van der Walt puts it, "a claimant is unable to find a cause of action in terms of existing law". ${ }^{61}$ In the event that direct application is not possible, section 8(3) explicitly provides a basis upon which a court will give effect to section $8(2)$ through the development or limitation of the rules of the common law. Roederer refers to the section 8(2) approach as "the direct-indirect horizontal application" and explains that "[h]ere the Constitution directly applies and persons are directly bound by section $8(2)$, but the remedy is not a separate constitutional remedy but one that integrates what is constitutionally required with the development of the common law under section $8(3)$ ". ${ }^{62}$

Direct or indirect horizontal application is subject to a limitation analysis that aims to balance competing interests in a manner that is "reasonable and justifiable in an open and democratic society based on human dignity, equality and freedom". ${ }^{63}$

In Khumalo O'Regan J did not question the finding of Van der Westhuizen J at the first instance hearing that compliance with section 39(2) effectively leads to the same result as compliance with sections $8(2)$ and (3). ${ }^{64}$ The effect of section 39(2) is that, in some cases, courts may simply rely on constitutionally compatible or inspired values in order to effect change to the common law. While there has been debate among scholars as to whether there is a difference between direct and direct-indirect application under sections 8(2)

582002 (5) SA 401 CC 27, available at <http://www.constitutionalcourt.org.za/Archimages/ 9442.PDF> (last accessed 21 March 2008).

59 Id at para 31.

60 Id at para 30.

61 Van der Walt "Progressive indirect horizontal application", above at note 57 at 352.

62 Roederer "The transformation of South African private law", above at note 57 at 503.

63 The general constitutional limitation provision under sec 36 of the South African Constitution.

64 Van der Westhuizen J presided over the first instance hearing of Holomisa $v$ Khumalo 2002 (3) SA 38 (T). Roederer "Post-matrix legal reasoning", above at note 57 at 62-70 and Van der Walt "Progressive indirect horizontal application", above at note 57 at 346. 
and (3) $)^{65}$ there has equally been a difference of views on the efficacy of 39(2) as a basis for a Bill of Rights compliance analysis. ${ }^{66}$ Roederer suggests that, from the perspective of practitioners, sections 8(2) and (3) are seen as provisions that conform to what a concrete legal provision ought to look like, as opposed to section 39(2), which is seen as lacking the concrete quality of a legal provision from which rights and duties may flow. Roederer makes a further observation on the basis of a textual and contextual analysis of sections 8(2)-(3) and 39(2) that "[t]he wording is different and they conjure up different images. However, upon a close reading the difference in the meaning of these two provisions reduces to a distinction between giving effect to a right through the development of the common law and developing the common law in the light of the spirit, purport and objects of the bill of rights"67 (emphasis added). The approach under section $39(2)$ is equally subject to a section 36 limitation analysis. ${ }^{68}$

South African jurisprudence sheds light on this issue. This article now attempts to outline its trajectory in light of two questions: whether the particular set of facts or legal issues are expressly or implicitly contemplated by the South African Bill of Rights as a source of obligations; and what is the scope of the court's authority to amend the common law, to create a right or to impose a duty in light of two conflicting interests.

\section{Express authority and the horizontal application of the Bill of Rights}

In addressing the question of when and under what circumstances private parties will be held to owe each other duties, one may first consider whether the factual or legal position in question is contemplated by the South African Bill of Rights as a source of obligations or rights. Arguments against there being sufficient authority to change the common law in order to impose a duty or create a legal right might be more forcefully made in the apparent absence of express or implied contemplation. This essentially captures the test laid down by the Supreme Court of Appeal in Fedlife Assurance Ltd $v$ Wolfaardt. ${ }^{69}$ The test stipulates that that the law (common law and legislation, including the Constitution of the Republic of South Africa Act, no 108 of 1996) should be interpreted as affecting vested rights and remedies only where the legislation expressly or by necessary implication requires or authorizes the modification of such rights or remedies (the Wolfaardt test).

65 Van der Walt id at 350-55 and Roederer id at 71-72. Roederer discusses the views of J de Waal, I Currie and G Erasmus The Bill of Rights Handbook (4th ed, 2001, Juta) at 63.

66 Van der Walt ibid and Roederer ibid.

67 Roederer id at 74.

68 Van der Walt "Progressive indirect horizontal application", above at note 57 at 349 and Fagan "Determining the stakes", above at note 3 at 84-90.

692002 (2) ALL SA 295 (SCA), available at <http://www.saflii.org//cgi-bin/disp.pl/za/cases/ ZASCA/2001/92.html?query=\%20Fedlife\%20Assurance\%20Ltd\%20V.\%20Wolfaardt> (last accessed 8 September 2007). 
The capacity of a court to modify a rule, doctrine or principle of the common law and consequently to impose a duty or confer a right need not necessarily be contingent on the Wolfaardt test; this was tacitly so in the Supreme Court of Appeal case of Kern v Minister of Safety and Security (Kern $S C A)^{70}$ which was overridden in the Constitutional Court case of Kern $v$ Minister of Safety and Security (Kern CC) ${ }^{71}$. In this case, the Constitutional Court jurisprudence on delict ${ }^{72}$ suggests that the legal position of a private individual under the common law is potentially affected by the content of the South African Bill of Rights provision even when the substantive fact or law in dispute is not addressed expressly or by implication. In Kern, the appellant found herself stranded in a Johannesburg suburb in the early hours of the morning. A male police officer offered to drive her home in an official vehicle in the company of two other male police officers. In the course of driving her home the police officers raped the appellant and abandoned her. The appellant instituted civil action against the minister of safety and security in delict and contended that the minister was vicariously liable for the actions of the police officers. The Supreme Court of Appeal held unanimously that the facts of the case did not bring it within the scope of the test for determining the liability of an employer vicariously in "deviation cases". ${ }^{73}$ For Scott JA the question was:

\begin{abstract}
"Whether the deviation was of such a degree that it can be said that in doing what he or she did the employee was still exercising the functions to which he or she was appointed or was still carrying out some instruction of his or her employer. If the answer is yes, the employer will be liable no matter how badly or dishonestly or negligently those functions or instructions were being exercised by the employee." 74
\end{abstract}

Scott JA noted that the court and counsel for the appellant were in agreement that the minister for safety and security could not be held vicariously liable for the actions of the policemen. Nevertheless, the appellant, on the basis of the constitution, urged the court to develop the common law in order to hold the minister vicariously liable. In response, Scott JA remarked that the appellant had not explained "[h]ow this could be done without imposing absolute liability on the state" and that this aspect "was simply left in the air". ${ }^{75}$

702005 (3) SA 179 (SCA), available at <http://www.supremecourtofappeal.gov.za/ judgments/sca_judg/sca_2004/45603.pdf> (last accessed 21 March 2008).

71 Case CCT 52/04 (CC 13 June 2005), available at <http://www.constitutionalcourt.org. za/uhtbin/hyperion-image/J-CCT52-04> (last accessed 21 March 2008).

72 The civil law concept of "delict" is broadly comparable to the common law concept of "tort". See Roederer "The transformation of South African private law", above at note 57 at $460-67$.

73 Kern SCA, above at note 70 at para 5.

74 Id at para 4.

75 Id at para 8. 
Apparently the court was not persuaded because counsel for the appellant did not build a comprehensive argument in support of applying section 39(2) to the facts and the law in the case. ${ }^{76}$ The court held that this was a matter that "would best be dealt with by the legislature should a change in the law be considered necessary"77 as it was not expressly or impliedly contemplated by the South African Bill of Rights as a source of rights and obligations.

This is valid to the extent that any attempt to impose a duty or limit a right must be argued and grounded in cogent analysis. However, this may be easily addressed. Under the South African Constitution, any attempted development of the common law through the imposition of a legal duty or limitation of a legal right implies that a court is required to assess conflicting interests often grounded in the provisions of the South African Bill of Rights. It is immaterial whether development of the common law is sought on the basis of section 8 (2)-(3) or 39(2). In either case the court is required to satisfy the following checklist or at least perform an analysis that corresponds to it:

(a) identify a right in the constitution which corresponds to the interest that is alleged;

(b) examine the applicability of the right;

(c) assess whether there is legislation that gives effect to the interest;

(d) provide a remedy if it is absent;

(e) investigate whether the application of the interest impinges on any other interest in a manner that, under section 36(1), is "reasonable and justifiable in an open and democratic society based on human dignity, equality and freedom". ${ }^{78}$

In other words, the fear of imposing strict liability on the state must not be the starting point for determining whether a common law rule or principle will be developed. Rather, a court should perform a balancing exercise on the basis of the limitation clause; the question of whether the imposition of strict liability would be a good thing in the circumstances must be decided on the understanding that it represents an equally important interest that should be protected. 79

On the subsequent appeal of Kern to the Constitutional Court, in relation to the test for establishing vicarious liability, the second ground of appeal argued that "if the Supreme Court of Appeal did not err in its application of the test,

76 Roederer "The transformation of South African private law", above at note 57 at note 263, quoting CJ Roederer "Law of delict" (2000) Annual Survey of South African Law 281 at 282: "whether the common law and its development comport with the values of the Bill of Rights is a thorny and contentious one. Without the aid of good advocacy it is understandably difficult for judges in the High Court and Supreme Court of Appeal to address the issue adequately" due to heavy case load, the adversarial system and lack of researchers.

77 Kern SCA, above at note 70 at para 10.

78 Roederer "Post-matrix legal reasoning", above at note 57 at 74.

79 Van der Walt "Progressive indirect horizontal application", above at note 57 at 349. 
the test should be developed in the light of section 39(2) of the Constitution as the result does not accord with the spirit, purport and objects of the Constitution". ${ }^{80}$ The appellant urged the court to consider that the facts and the law applicable in the case were contemplated by the South African Bill of Rights and, in particular, the "constitutional right to freedom and security of the person". 81 Her argument succeeded. In a unanimous judgment, O'Regan J explained the nature of the constitution, ${ }^{82}$ emphasizing its "pervasive normative effect". Like the German Constitution, aside from the negative subjective rights an individual enjoys, it has "an objective normative value system" that guides the common law. Consequently, "it is within the matrix of this objective normative value system that the common law must be developed". 83

The court addressed the question of when the common law may be altered in the context of section 39(2). O'Regan J adopted the view of Moseneke J in $S v$ Thebus and Another ${ }^{84}$ that a rule of the common law may be altered either when it is inconsistent with a provision of the constitution or when it is consistent with a specific constitutional provision but is nevertheless out of step with the spirit, purport and objects of the constitution. ${ }^{85}$ She clarified the "development" of the common law under the constitution in light of section 39(2) (as distinct from the "incremental" development of the common law) as: first, the removal of those aspects of the common law that are inconsistent with the constitution; and, second, the "infusion" of the normative values of the constitution into an adjudicative process "when some startling new development of the common law was in issue." 86

Crucially, O'Regan explained how the juxtaposition of the facts presented with the orthodox principles of vicarious liability fell short of giving effect to the requirements of the constitution under section 39(2):87 the "... question of the protection of Ms K's rights to security of the person, dignity, privacy and substantive equality are of profound constitutional importance". ${ }^{88}$ The appellant was entitled to repose trust in the three policemen ensuring her safety and security by virtue of the responsibility placed on them by statute and the constitution. ${ }^{89}$ By virtue of the policemen's statutory and constitutional duty, the appellant had a legitimate expectation that they would protect her

80 Kern CC, above at note 71 at para 14.

81 Id at para 14. More specifically the appellant based her argument on the rights: to be free from all forms of violence from either public or private sources (sec 12); to dignity (sec $10)$; to privacy (sec 14$)$; and to substantive equality (sec 9).

82 Id at para 15.

83 Ibid.

842003 (6) SA 505 (CC); 2003 (10) BCLR 1100 (CC) para 28; and Kern CC id at para 16.

85 Kern CC ibid.

86 Id at para 16 .

87 Id at paras $45-58$.

88 Id at para 18.

89 Id at paras 18 and 52. 
rights to personal dignity and freedom. The policemen had not only failed in their duty but also actively breached the appellants' rights purposely; therefore their employer's obligation (as well as their own) to prevent crime had not been met. ${ }^{90}$ Their wrongful acts were sufficiently connected to the purpose of their employer that the minister of safety and security was vicariously liable. ${ }^{91}$ This analysis of O'Regan $\mathrm{J}$ corresponds to the checklist analysis referred to above. ${ }^{92}$

Having addressed the question whether the South African Bill of Rights contemplates facts or legal issues as the basis for imposing obligations, this article now addresses the scope of authority a South African court may have to amend the common law on the basis of a Bill of Rights provision.

\section{Scope of authority and the horizontal application of the Bill of Rights}

Questions may be raised over the scope of a court's authority to amend the common law, create a right or impose a duty in the light of the conflict between different aspects of the South African Constitution. A Bill of Rights provision in the South African Constitution that has given rise to considerable uncertainty is section 26(3) against eviction from one's home. On its face, this provision requires the common law right to eviction to be modified..$^{93}$ It provides that: "No one may be evicted from their home, or have their home demolished, without an order of court made after considering all the relevant circumstances. No legislation may permit arbitrary evictions." This provision clearly owes its place in South Africa's Bill of Rights to the horrendous history of apartheid, manifested in the deprivation of "lawful owners and occupiers of their land" and the disregard of "the land rights and interests of millions ... rendering them landless in fact or effectively preventing them from gaining access to land". 94

Although section 26(3) spawned considerable and complex land reform laws (both statutory and common law), this article is confined to case law that highlights the effect and scope of section 26(3) on the common law applicable to the eviction of offending tenants. ${ }^{95}$ Case law and academic analysis illuminate the South African courts' approaches to the question of a court's scope of authority. These approaches diverge in emphasis in their attempt to mediate the palpable tension between the constitution's transformative requirements

\footnotetext{
90 Id at para 22.

91 Id at paras 51-58.

92 See text above at note 78 .

93 Van der Walt "Exclusivity of ownership", above at note 57 and AJ Van der Walt "Exclusivity of ownership, security of tenure and eviction orders: A model to evaluate South African land reform legislation" (2002) Journal of South African Law 254.

94 Van der Walt "Exclusivity of ownership", above at note 57 at 399.

95 Ibid. R Keightley "The impact of the Extension of Security of Tenure Act on an owner's right to vindicate immovable property" (1999) 15 SAJHR 277; Van der Walt "Exclusivity of ownership", above at note 57; and A Van der Walt "Ownership and eviction: Constitutional rights in private law" (2005) 9 Edinburgh Law Review 32.
} 
and the desire to insulate the common law from the constitution's radical tendencies. This has led to a polarizing debate in the media, among practitioners in the real property market, and in the courtroom. There is, however, a basic consensus that eviction as a fact or a legal issue is expressly contemplated by the constitutional provisions against arbitrary eviction. The difficulty arises with regard to the scope a competent court has to amend the common law on eviction. The question is whether the jurisdiction of the common law is eclipsed in a situation where, on the basis of a rent or lease agreement, eviction is sought as a result of cancellation or lapse of time.

In Ross $v$ South Peninsula Municipality, the provincial Cape High Court accepted that section 26(3) had amended the common law rules relating to eviction and consequently it extended its reach to normal rent situations. ${ }^{96}$ South Peninsula Municipality had sought to evict Mrs Ross, the appellant, on the basis of a court order. The respondent alleged that the appellant occupied its property illegally. On appeal, the question that the court was required to determine was whether section 26(3) placed a burden on the owner of land to explain "the relevant circumstances justifying the eviction of a person in possession of the owner's property if it is his or her home". ${ }^{97}$ Significant in this case is Josman AJA's holding that section 26(3) had modified the common law rules established in Graham $v$ Ridley ${ }^{98}$ and that the modification equally applied to eviction from a home. ${ }^{99}$ It underscores the supremacy of the constitution over the common law.

A couple of justifications have been advanced as rationales for section 26(3). It is viewed as a basis for subjecting eviction to "rigorous due process of qualifications and controls" in order to attain equity and fairness. ${ }^{100}$ It is also seen as a basis for avoiding the repetition of unjust, oppressive and exclusionary methods used to evict lawful occupiers under apartheid. ${ }^{101}$ The position taken by Josman AJA in Ross rests on the former rationale while the latter underlies Betta Eiendomme (Pty) Ltd $v$ Ekple-Epor. ${ }^{102}$

In Betta Eiendomme, the provincial Witwatersrand High Court held that section 26(3) was not applicable to "normal landlord and tenant" contractual situations. Andre van der Walt observed that at issue was whether, in relation to the common law, provisions of this nature are "purely procedural restrictions" or "substantive and institutional amendments" to the right of

962000 (1) SA 589 (C); R Keightley "When a home becomes a castle: A constitutional defence against common-law eviction proceedings: Ross $v$ South Peninsula Municipality" (2000) 17 South African Law Journal 26 and Van der Walt "Exclusivity of ownership", above at note 57 at 394.

97 Keightley id at 27

981931 TPD 476. Traditionally a landowner was simply required to establish ownership of land and possession of the land by the occupier.

99 Keightley "The impact of the Extension of Security of Tenure Act", above at note 95.

100 Van der Walt "Exclusivity of ownership", above at note 57 at 399.

101 Id at 373-74.

1022004 (4) SA 469 (W). 
ownership. ${ }^{103}$ The essence of the court's view is that the common law on eviction of tenants under normal rent agreements or leases of residential property was not altered in any way by section 26(3). Any suggestion to the contrary ought to be made very explicit in legislation as is the case with the land reform statutes. The court specifically rationalized section 26(3) on the basis that it was "a never again provision" designed to prevent the recurrence of apartheidstyle evictions. Section 26(3) is thus, according to the court, not a mechanism that imposes "rigorous due process of qualifications and controls". ${ }^{104}$ It is not intended to limit the common law right to seek eviction or act as a measure that vindicates the right of ownership to land.

The problem with this view is that it ignores the supremacy of the constitution, implying that, in the relationship between the constitution and the common law, there are enclaves that are fenced off from the effects of constitutional provisions or values. The key must be the "pervasive normative effect" of the constitution and not the method by which the common law evolves. Furthermore, emphasis on the "never again" rationale neglects the fact that this is but one side of the constitutional legitimacy argument. The constitution is also forward-looking, and a balance must be struck between these seemingly conflicting values. The requirement to place "relevant circumstances" before the court does not imply victory on the part of the occupant or loss on the part of the owner.

The restrictive approach of the court in Betta Eiendomme evidences a desire to insulate the common law from radical transformative tendencies by applying it in isolation from the values that gird the constitution. The Constitutional Court in Kern clearly rejects this desire, asserting that South Africa has one legal system with the constitution at its apex and the common law subsumed in it. It is the constitution that must set the pace and not the common law. The concern raised by this article is not whether the court in Betta Eiendomme was correct in its determination that section 26(3) is inapplicable to normal rent situations. It may be argued that the approach taken by the judge in that case reflects in part the problem identified by Lon Fuller pertaining to the difficulty of attaining legislative clarity. ${ }^{105}$ In any event Betta Eiendomme was overturned by the Supreme Court of Appeal in Brisley $v$ Drotskey where it ruled that section 26(3) was applicable to normal rent situations. ${ }^{106}$ Rather, this article is concerned with the judicial appreciation of the common law-changing function of the South African Bill of Rights and its associated values, and with the judicial understanding as to when such a function may be brought into play.

The judgment in Betta Eiendomme indicates a profound inability to accept that the common law concept of ownership and its incidentals, as a symbol

103 Van der Walt "Exclusivity of ownership", above at note 57 at 375.

104 Id at 399.

105 L Fuller The Morality of Law (1969, Yale University Press) especially chap II at 63.

1062002 (4) 1 SCA. 
and a practical expression of liberty, may paradoxically be a source of the opposite of liberty. Fencing off the common law right to eviction that a landowner enjoys in a "normal rent situation", while taking a narrow view of section 26(3) as a "never again" provision, implies the association of unjust, oppressive and exclusionary tendencies with the relationship between the state and the individual. The court's position suggests a reluctance to see the common law as a conduit of such tendencies in private transactions. This discussion on South Africa has shown that courts in that country have attempted to grapple with the deep jurisprudential issues of indirect horizontality in a structured fashion. In contrast, debate in the Malawi courts on horizontality has been limited. However, judicial intervention may be made by appealing to the Malawi Bill of Rights and the values that underlie the Malawi Constitution. This article now examines the prospects of success for such an appeal.

\section{CHARTING A WAY FOR HORIZONTALITY: DEVELOPING THE COMMON LAW IN MALAWI}

The courts in Malawi have on occasion applied the Bill of Rights directly to private relationships. It is not clear why the indirect horizontal method has had limited application. ${ }^{107}$ Possibly legal practitioners do not expect a positive reception from the courts as the Liquidator's case suggests. To use Roederer's observation, the indirect method does not conjure up the image of a proper concrete legal provision which gives certainty. Equally, the lack of exposure to substantive jurisprudence and the technical aspects on indirect horizontality may suggest the answer. Therefore, South African jurisprudence provides a possible guiding framework.

This article has shown that the tenant worker operates without the protection of section 25 of the Private Estates Act: the guarantee of adequate security of tenure. The common law remedies are inadequate or nonexistent. This calls for judicial intervention through indirect horizontality. Section 13(e) of the Malawi Constitution expressly or impliedly envisages this situation as a premise for invoking horizontality indirectly. The scope of the court's authority may equally be gleaned from sections 21 and 29 of the Bill of Rights and from values underlying them. The tenant worker's circumstances call for intervention through the modification of private law pertaining to land access contracts. Consequently, the competent common law judge is invited to make private law, through the constitution, responsive to the tenant worker's environment. Intervention to enhance tenure adequately would address the needs of the tenant worker as an economic actor, a legal subject and as an individual for whom human dignity is non-negotiable. Like the Interim and South African Constitutions, the Malawi Constitution is endowed with

107 See the discussion of The Liquidator's case and Granger Nkhwazi, above at notes 7 and 16 respectively. 
jurisprudentially transformative qualities, as observed by Gloppen and Kanyongolo. ${ }^{108}$ Grievances over economic and social welfare constituted an important rallying point in Malawi's re-democratization process in the early 1990s and ostensibly are reflected in the constitution. ${ }^{109}$

In order to determine the circumstances in which indirect horizontality will apply to private relationships on the private estate, the value-based approach elaborated by O'Regan J in the cases of Khumalo and Kern CC must be adopted. It stipulates that a rule of the common law may be altered "when a rule of the common law is consistent with a specific constitutional provision but is nevertheless out of step with the spirit, purport and objects of the Constitution".110 It is arguable that the "spirit, purport and objects" of the constitution include the value of promoting the interests of the marginalized and those susceptible to exploitation. In the Malawi Constitution the value-based approach is justified by sections 10(2), 11(1) and (2).

This entails that the common law cannot be fenced off from the values of the constitution. The constitution and the common law constitute one legal system and one law, and in appropriate situations the values encapsulated in the constitution may be invoked to impact on decision making under the common law. This echoes observations made by Chaskalson $\mathrm{P}$ in Pharmaceutical Manufacturers Association of SA: In re: ex parte President of the RSA who observed that "There are not two systems of law, each dealing with the same subject matter, each having similar requirements, each operating in its own field with its own highest court. There is only one system of law". ${ }^{111}$ Indeed, this entails that no single area of law will be insulated from constitutional scrutiny, as demonstrated by Ross $v$ South Peninsula Municipality and Betta Eiendomme.

The factual and legal position of the tenant worker is contemplated by the values in the Malawi Constitution, expressly and implicitly. Section 13(e) provides that state practice must be directed toward "improvement of the quality of life in rural communities" and recognition of "rural standards of living as a key indicator of the success of government policies". ${ }^{112}$ The tenant worker's contract is essentially a land access contract constituted in rural Malawi involving a defined class of rural dwellers: tenant workers, as envisaged by section 13(e). Consequently the uplifting of the social and economic position of the tenant worker will be a baseline for assessing the success of general welfare policy regarding rural communities.

108 Gloppen and Kanyongolo "Courts and the poor", above at note 5 at 264.

109 Ibid.

110 Kern CC, above at note 71 at para 16 .

111 Case CCT 31/ 99, available at: <http://www.constitutionalcourt.org.za/Archimages/1461. PDF> (last accessed 21 March 2008) at para 44.

112 Sec 13(e) is a Principle of National Policy, by which organs of the state are directed to abide. The "state" here includes the judiciary in accordance with sec 15(1) of the Malawi Constitution. 
A counter argument may be made that intervention in the context of section 13(e) amounts to land reform through the back door and that the constitution does not allow this. While the constitution does not expressly mention land reform, some of its provisions may be construed as allowing for it. ${ }^{113}$ From a perspective of pragmatism and not normativism, land reform is, for the most part, best dealt with by the executive and the legislature through the formulation and implementation of appropriate legislation and policies. However, the judiciary equally has a role to play in such a process through creative and activist interpretive practices that give effect to the requirements of the constitution, particularly where legislative and executive inertia are displayed. As this article has shown, the executive and the legislature in Malawi have not yet been able to deal with the situation of the tenant worker.

Section 29 of the Malawi Constitution encapsulates a value that militates in favour of the tenant worker as an economic actor who aims to attain an economically viable contractual relationship. It guarantees every person "the right freely to engage in economic activity, to work and to pursue a livelihood anywhere in Malawi". A counter-veiling argument may be made that section 29 does not extend to modification of relations based on real property, but rather personal property transactions. In response the following argument may be made. Unless specific legislation constitutes a tenant worker's contract as a relationship based on property it is, on the basis of facts available, open to characterization as either based on property or personal relations. Nonetheless, section 29 potentially has the ability to shore up the contractual capacity of a person regardless of the character the contract is veiled with. This view is justified by the guarantee to the right to privacy under section $21 .{ }^{114}$ Section 29 may be construed as a guarantee of the performance of a specific act, under a particular condition, and thus may be read as a guarantee of the rights to "engage in economic activity", to "work" and to "pursue a livelihood" in conditions of freedom. It may also be interpreted as a guarantee of the right to a prior condition before a specific act is performed. Thus the section may be read as a guarantee of "freedom" as a necessary condition precedent to engagement in "economic activity", "freedom" to "work" and pursuit of a livelihood. ${ }^{115}$

Regardless of construction, freedom as a concept occupies a central place in the provision. While the tenant worker's contract may be construed to pertain to economic activity, work or a livelihood, the concept of "freedom" captures the nature of the intervention the tenant worker requires in relation to

113 For example, the distinction between "deprivation" and "expropriation" of property in secs 28(2) and 44(4) or the "property clauses" in the Malawi Constitution.

114 See HJ Snijders "Privacy of contract" in Zeigler (ed) Human Rights and Private Law, above at note 14 at 105 for a European perspective on contract and horizontality based privacy.

115 Freedom is here understood in a negative sense as the absence of interference or constraint, and in the positive sense as facilitation of autonomy through the removal of interference or constraint. 
"adequacy of security of tenure". On the basis of the right to privacy, the tenant worker is either entitled to engage in a contract in conditions of freedom or must be assured of freedom in order to operate effectively in a contractual situation. Freedom here entails privacy and autonomy as a fundamental concern, and adequacy of security of tenure is essential in satisfying this concern.

The concept of freedom as understood here is also intimately linked to the values incorporated in the idea of the individual's dignity, espoused in section 12(iv) of the Malawi Constitution as: "The inherent dignity and worth of each human being requires that the State and all persons shall recognize and protect fundamental human rights and afford the fullest protection to the rights and views of all individuals, groups and minorities whether or not they are entitled to vote."116

The view of Oscar Schachter in relation to the concept of dignity is useful here in explaining the fundamental nature of the concept of freedom and its implications in this case. ${ }^{117} \mathrm{He}$ observes that the notion of human dignity incorporates "a complex notion of the individual. It includes recognition of distinct personal identity, reflecting individual autonomy and responsibility" and that, at a deeper analytical level, it is closely linked to "material needs" in that:
"Few will dispute that a person in abject condition, deprived of adequate means of subsistence, or denied the opportunity to work, suffers a profound affront to his sense of dignity and intrinsic worth. Economic and social arrangements cannot therefore be excluded from a consideration of the demands of dignity. At least, it requires recognition of a minimal concept of distributive justice that would require satisfaction of the essential needs of everyone."118

Schachter's argument may equally be applied to the tenant worker on the basis that intervention to enhance tenure adequately would serve the objective of addressing autonomy, hence the needs of the tenant worker as an economic actor and as an individual for whom human dignity is integral.

In turn, the private estate owner may raise the question of whether the court has the authority to interfere with his own freedom, a pillar of the orthodox common law contract, which bases its abhorrence of interference on the freedom and sanctity of contract. However the notion that a contractor may not freely participate in contractual relationships in some circumstances is based on the premise that contracts are capable of acting as a medium for

116 Sec 12(iv) is a fundamental principle of the Malawi Constitution and thus an important value.

117 O Schachter "Human dignity as a normative concept" (1983) 77 American Journal of International Law 848.

118 Id at 851. 
the breeding and perpetuation of unfair practices. Unfairness may arise out of a simple inequality of bargaining positions or out of culpable interpersonal conduct that is a consequence of unethical self-serving behaviour and this is implicitly recognized by sections 21 and 29 of the Malawi Constitution. Roger Brownsword has discussed the principle of freedom of contract in the following unconventional terms:

\begin{abstract}
"[T] he principle of freedom of contract (as embedded in the institution of contract law) should not be thought of as a licence to contract with whomsoever one wishes in what ever terms one wills. Rather it is a principle enjoining regulatory restrain in relation to transactional freedom. So interpreted the principle holds that, in the absence of "good reasons" contractual freedom should not be restricted ... where a legal system is committed to respect for human rights ... it follows that the values represented by those rights must be incorporated into the body of 'good reasons' on the basis of which contractual freedom may be legitimately restricted."119
\end{abstract}

Thus, judicial interference in a tenant worker's contract on the basis of sections 21 and 29 would simply be recognizing the peculiarities or "good reasons" that attach to that contract. Intervention is premised on a contextual analysis of sections 13(e), 21 and 29, coupled with an historical assessment of the social and economic position of the tenant worker and an informed appreciation of private law. Interference is also premised on the absence of statute or its ineffectiveness and on there being unregulated spaces in private relationships between the privileged and the un-privileged. The peculiarities of this unregulated space historically inform that unjust and exploitative tendencies flourish in it or, at least, that it provides conditions for such tendencies to flourish; indeed, empirical evidence reinforces this.

The potential interference with a tenant worker's contract raises a further pre-emptive abhorrence of the spectre of unjustified interference with the constitutional and the common law right to property. Orthodox common law property jurisprudence sets store by the exclusive possession of a defined common law estate in land. ${ }^{120}$ From an interventionist view, this is counterbalanced by equally legitimate interests of society found in the general welfare requirements of sections $13(\mathrm{e})$ and 29 and the personal interests of the tenant worker captured in sections 21 and 29 which demand action in a variety of ways. They demand that a judge conceive estate ownership as a relational phenomenon and the tenant worker's contract as a land-access regime that is primarily contractual. The critique of the court's approach in Betta

119 R Brownsword "Freedom of contract, human rights and human dignity" in D Friedmann and D Barak-Erez (eds) Human Rights in Private Law, above at note 3, 181 at 183.

120 K Gray "Property in common law systems" in GE van Maanen and AJ Van der Walt (eds) "Property law on the threshold of the 21st century" (proceedings of International Colloquium, Maastricht, 28-30 August 1996, published by Maklu) 235 at 247. 
Eiendomme may equally be applied, however. The private estate owner, as an owner of the highest estate in land, interacts with tenant workers, members of the public, in many ways. When he enters into private contractual relationships with members of the public, he wields market power, which he uses unfairly against tenant workers. It is on this basis that intervention is advocated through the subjection of the relevant common law rules to the Bill of Rights. Interference with ownership by the private estate owner is ultimately a mechanism for realizing the values of the Malawi Constitution in concrete form.

Abhorrence of intervention may also be premised on the relative images that value- and text-based approaches have invoked among lawyers, as observed by Roederer. ${ }^{121}$ Similarly, in the Malawi context, a court must satisfy Roederer's checklist or at least perform an analysis that corresponds to it. The checklist demands that a court carry out a balancing exercise, taking into account the limitation clause; this process takes into equal account any interest that may be expressed in opposition.

\section{CONCLUSION}

There is no doubt that the Malawi Constitution potentially retains two very important and complimentary values. On the one hand, the requirement that the competent common law judge must ensure the common law is in line with the "principles and provisions" of the constitution. Furthermore, the competent common law judge is required to develop "appropriate principles of interpretation" which facilitate the subjection of the common law to relevant constitutional provisions. On the other hand, the Malawi Constitution, as with the South African Constitution, was intended by its drafters to provide a basis for the development of a transformative jurisprudence. This aspect of the Malawi Constitution, coupled with specific provisions that call for the horizontal application of the Bill of Rights to the common law, places the onus on the common law court to contribute effectively to the political goal of positively transforming the lives of the economic and social underclass. Considered together, these values have the potential to enable a judge to ensure that the horizontal application of the Bill of Rights extends to indirect application.

The course taken by the South African Constitutional Court may legitimately constitute a model for Malawi courts. The standards and values by which transformation ought to be assessed are provided for in the Malawi Constitution. An attempt has been made to demonstrate how the indirect method might work through the application of specific constitutional provisions (sections 13(e), 21 and 29) to the tenant worker's situation on a Malawi private estate. However, Malawi does not have a sufficiently robust judicial constitutional rights discourse on the horizontal application of

121 Roederer "Post-matrix legal reasoning", above at note 57. 
human rights. Consequently, it is only proper that the courts seek guidance from developments in other jurisdictions, just as the drafters of the Malawi Constitution drew from the experiences of other jurisdictions. This option has a strong foundation in section 11(2)(c) of the Malawi Constitution which provides that, in applicable cases, courts ought to "have regard to comparable foreign case law".

That said, the successful implementation of this is dependent on overcoming hurdles that are not unique to the jurisprudential landscape in Malawi. First, the common law is often obscure and remote to those upon whom it impacts. A person in the position of the tenant worker is a classic example. The remoteness of the law relates to, among other things, financial incapacity and the sheer physical distance that separates the person seeking justice from a legal practitioner's office and the premises of the law court. Access to legal expertise entails that the tenant worker ought to have the financial capacity to secure the services of a legal practitioner who invariably is located in a city. The private estates are essentially institutions that are located in rural parts of the country that do not have access to many basic services.

The obscurity of the law points to the intellectual and cultural gulf that exists between the formal and complex world of lawyers, the common law and legislation, and the world of the manual agriculture worker on a private estate. The paradox noted by Yash Ghai in relation to the supremacy of the traditions and trappings of the common law and the lack of connection that people have with the common law in anglophone Africa is particularly apposite in this case: "The common law does not touch the lives of many people, its ideologies, assumptions and rationalizations have little relevance for them. The common law is, nevertheless, the law of the rich and the powerful."122

Secondly, legal practitioners need to be educated on the view that the common law is not a rigid and inflexible normative body insulated from constitutional provisions. Specifically, lawyers must be open to litigation techniques and approaches from other jurisdictions. Lastly, the judiciary must equally understand the constitutional value in courts being receptive to what might otherwise appear to be unconventional jurisprudence. While courts are rightly required to maintain consistency in a legal system, the history of the development and application of the common law is replete with examples of creative conceptualization of consistency. Therefore, in the specific case of the tenant worker considered above, while the common law concept of freedom of contract is conventionally seen as an enabling concept, it may also be creatively conceived as a mechanism for restraint. In this way the court may effectively contribute to the political goal of positively transforming the lives of the economic and social underclass as envisaged in the Malawi Constitution.

122 G Yash "Law, development and African scholarship" (1987) 50 Modern Law Review 750 at 751. 